West Virginia Agricultural and Forestry Experiment Davis College of Agriculture, Natural Resources Station Bulletins And Design

$12-31-1957$

\title{
Costs and mechanical injury in handling and packing apples
}

Homer C. Evans

R. S. Marsh

Follow this and additional works at: https://researchrepository.wvu.edu/ wv_agricultural_and_forestry_experiment_station_bulletins

\section{Digital Commons Citation}

Evans, Homer C. and Marsh, R. S., "Costs and mechanical injury in handling and packing apples" (1957). West Virginia Agricultural and Forestry Experiment Station Bulletins. 416.

https://researchrepository.wvu.edu/wv_agricultural_and_forestry_experiment_station_bulletins/397

This Bulletin is brought to you for free and open access by the Davis College of Agriculture, Natural Resources And Design at The Research Repository @ WVU. It has been accepted for inclusion in West Virginia Agricultural and Forestry Experiment Station Bulletins by an authorized administrator of

The Research Repository @ WVU. For more information, please contact ian.harmon@mail.wvu.edu. 
Costs and

Mechanical Injury

in Handling and

Packing Apples

ULLETIN 416 JUNE 1958

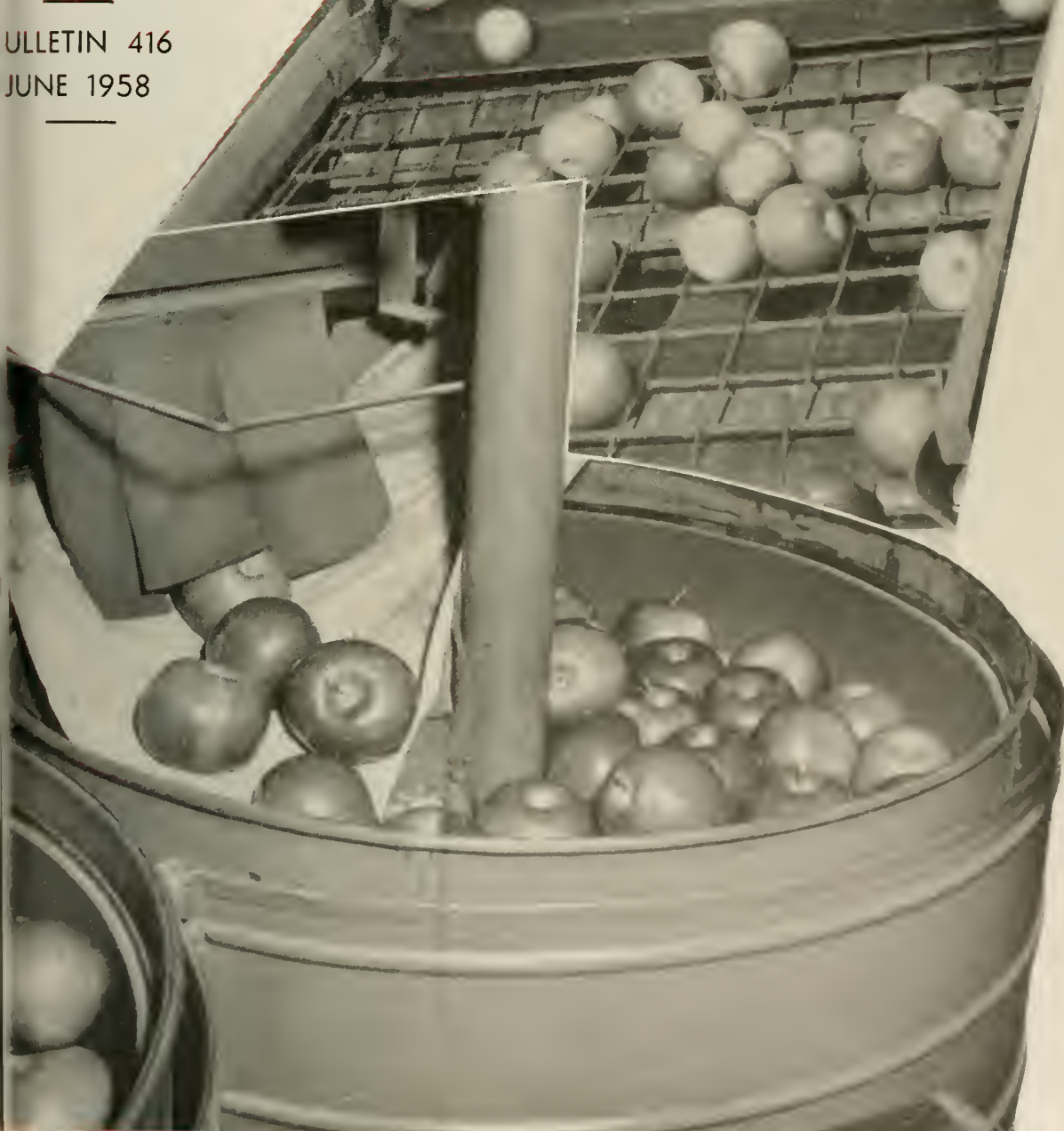




\section{THE AUTHORS}

Authors of Cost and Mechanical Injury in Handling and Packing Apples are Honer C. Evans and Ray S. Marsh. Homer C. Evans is Associate Agricultural Economist in the Agricultural Experiment Station, and Ray S. Marsh is Professor and Head of Horticulture in the College of Agriculture, Forestry, and Home Economics, and Horticulturist in the Agricultural Experiment Station.

West Virginia UNiversity Agriceltural Experiment Station

College of Agriculture, Forestry, and Home Economics

A. H. Vanlanidnghan, Acting Director MORGANTOWN 


\section{Preface}

THIS is the first of a series of reports covering work clone on handling methods and on costs of packing apples in the Appalachian Area, The over-all project has the following objectives: to discover walys of reducing costs of handling, packing, and storing apples under condition prevailing in the Appalachian Area, and to determine the extent of mechanical injury to apples caused by diflerent equipment and methods, However, this particular report cleals only with the costs of packing and haudling apples, and the degree of mechanical injury for the 1956 and 1957 seasons. An evaluation of the relative efficiency of different milchines and work methods will be made in another report, using time and motion and work-sampling data.

This study was carried out jointly by West Virginia University and the Agricultural Marketing Service (AMS), United States Department of Agriculture (USDA). It is a part of Northeast Regional Project VE.I-19, "Handling Methods and Costs in Storing and Packing Apples." 


\section{Acknowledgement}

The authors appreciate the cooperation of the apple growers and packers in the Appalachian Area. They were most helpful in making data avalable and in permitting the researchers to study their operations.

The following personnel from the Agricultural Marketing Service, United States Department of Agriculture have contributed much to this study: Robert Bogardus, Stanley W. Burt, William H. Elliott, Joseph H. Herrick, Jr., Alden C. Manchester, Loyd C. Martin, and Jules V. Powell. They helped in the plamning of the project, the collection of data, and have given helpful suggestions in the preparation of this manuscript.

The pictures were taken by Darid Creel of the West Virginia University Agricultural Experiment Station and USDA persomel. 


\section{Costs and Mechanical Injury in Handling and Packing Apples}

\section{Introduction}

THIS report is concerned with the costs of packing and handling apples. and with the extent of mechamical injury to apples in a sclected group of packing houses which use the various equipment and work methods found in the Appalachian Area in 1956-57. No attempt is made o explain variations in costs anong plants because there were differences which are not accounted for in this report. These differences include the vide variation in management and supervision, and the wide variation of work time and idle time among plants and among jobs within a lant. The effects of these variables will be cliscussed in another report.

\section{jelection of Packing Houses Studied}

A preliminary survey was made of the larger packing houses in the Ippalachian Area between Winchester, Virginia, and Mercersburg, Pennylvania, to detemine the different types of equipment and the work nethods being used in the larger packing houses. The packing of 50,000 ushels per season was set as the approximate lower limit of the packing ouses to be surveyed. Schedules were taken on the operations of 36 racking houses: $17 \mathrm{in}$ West Virginia, 8 in Virginia, 4 in Maryland, and in Pennsylvania. From these, 8 were selected for detailed study. They ad all the different types of equipment and work methods found in the 6 plants originally surveyed. A diversity of equipment and work icthods was needed to give a picture of costs and injury under present onditions-pictures 1 and 2. In the next phase of this study, this diverty will serve as the basis for determining the most efficient of the resent methods of handling and packing apples.

\section{'art l: PACKING AND HANDLING COSTS}

\section{rocedure}

L.L packing-house labor costs were figured per "packed container." The net weight of packed containers varied, depending on the variety of apple and the type of container; however, each contaniner held 


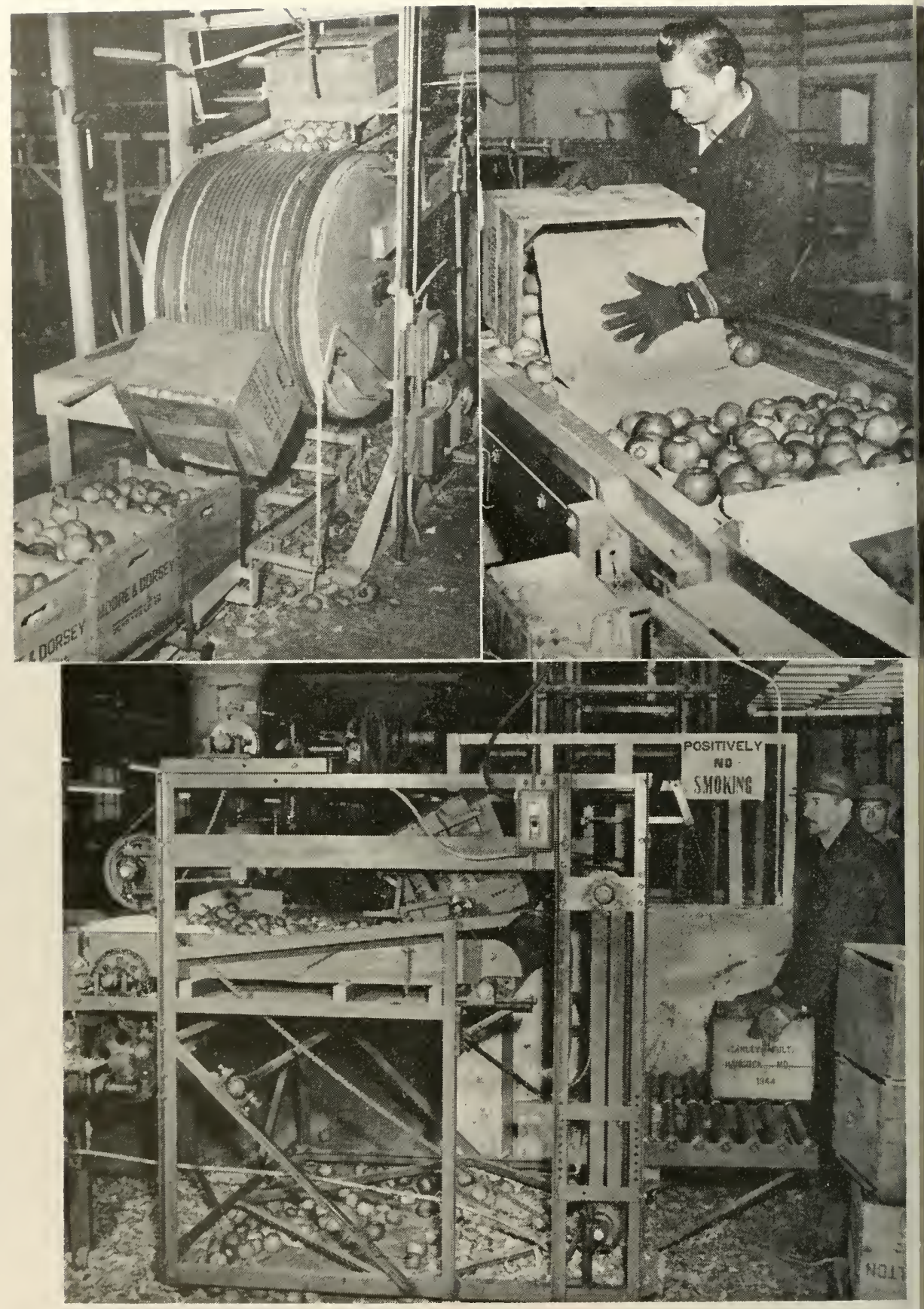

PICTURE 1-Three methods of dumping apples. 

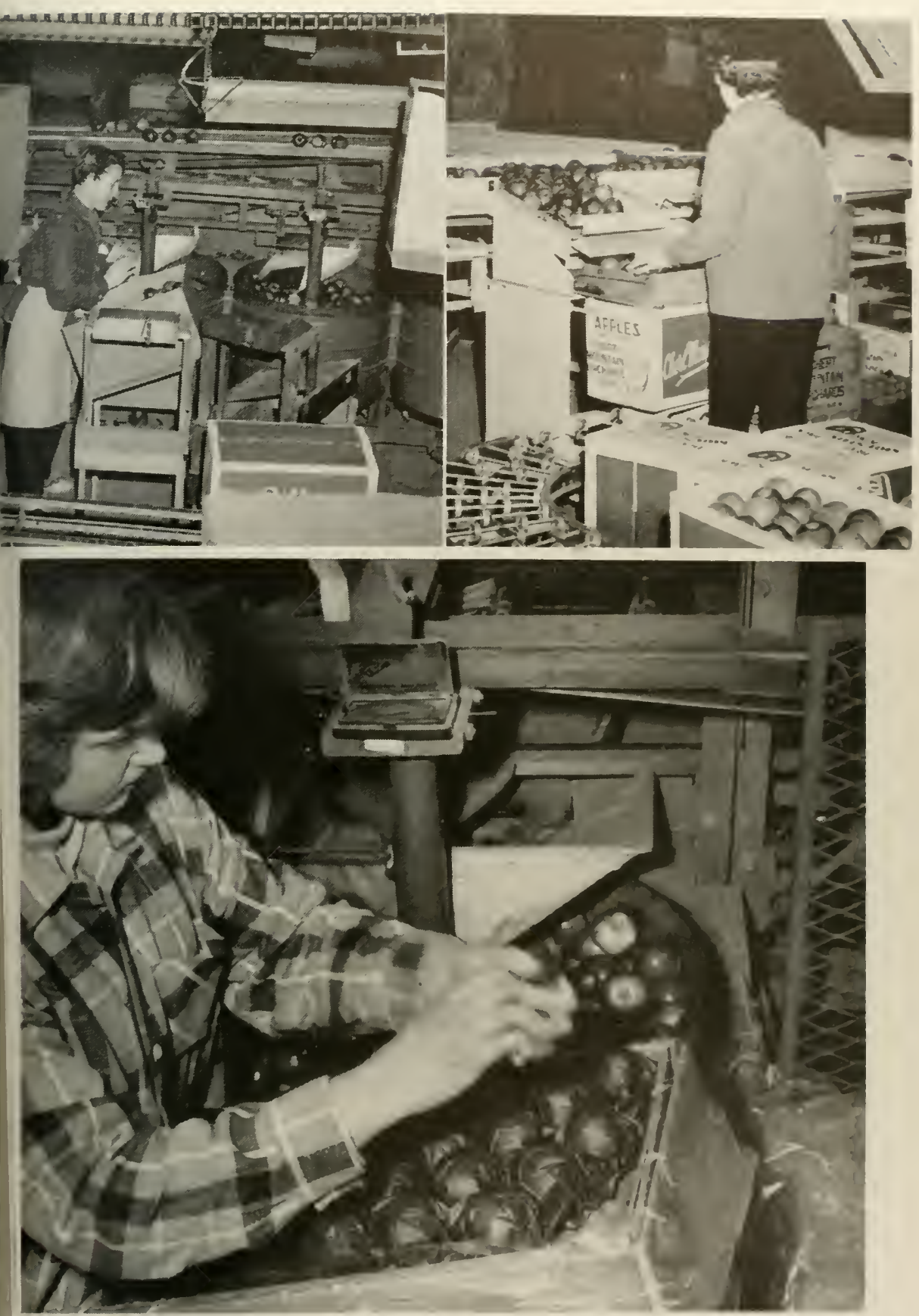

PICTURE 2-Three methods of tray packing. 
approximately one bushel. The following were counted as packed containcrs: tray pack, Northwest box, bushel basket, filteen three-pound bags, twelve lour-pound bags, and nine five-pound bags. In cases where sized and graded apples were stored temporarily in bulk, the field crate was counted as a packed contaner for purposes of figuring per-mnit dumping, grading, and overhead costs.

In determining labor costs, the time required for perloming each of the various packing-house jobs was recorded. In each case, time repuirements were based on total man-minutes of the workers engaged in the jobs under observation. Unit-time-requirements were obtained by dividing total man-minutes by the number of packed containers produced during the time periods observed. Labor costs were obtained by multiplying the unit-time-requirements for the various jobs by the wage rate paid for each job. Data were taken in each packing housc for approximately one week.

Overhead and material costs were obtained from the owners anc managers of the packing houses studied. The costs were taken eithes from accounting records of the firms or from the owners' estimates is calses where records were not kept in the detail needed. In most cases estimates were obtained for repairs, heat, power, telephone, insurance and taxes because costs for these services had to be allocated between packing operations and other operations, such as storage and genera orchard operations. Buildings werc depreciated at a rate of $3 \mathrm{~s} / 3$ per cen per year, and equipment was depreciated at the rate of 10 per cent pes year. No charges were made for interest on investment. Per-ınit overheac costs were obtained by dividing total overhead costs for the year by thi number of bushels packed in the packing house for the season.

\section{Packing Costs}

\section{LABOR COSTS}

lacking labor costs start with the apples in temporary storage nea the dumping operation and include all labor involved through th stacking of the packed containers. Labor requirements for certain job are independent of the type of container used while packing (or fillin the container), and lidding labor is related to the type of container. Th lollowing operations must be performed in about the same manner, re gardless of the type of container used: dumping, grading, packing th table culls, stamping, weighing, tallying, stacking entpty boxes, stackin packed containers, supervising, and miscellaneous. Packing-house labo costs are divided into two groups: "general labor," which includes labo for the above listed jobs, and "packing and lidding labor." Figure shows packing-house general-labor costs. The range in costs among plant 
Figure 1. Packing House General Labor Costs Per Packed Container in Eight Packing Houses, Appalachian Area, 1956.

(General packing house labor includes all packing house labor involved in packing apples from dumping through stacking the packed container except packing and lidding labor.)

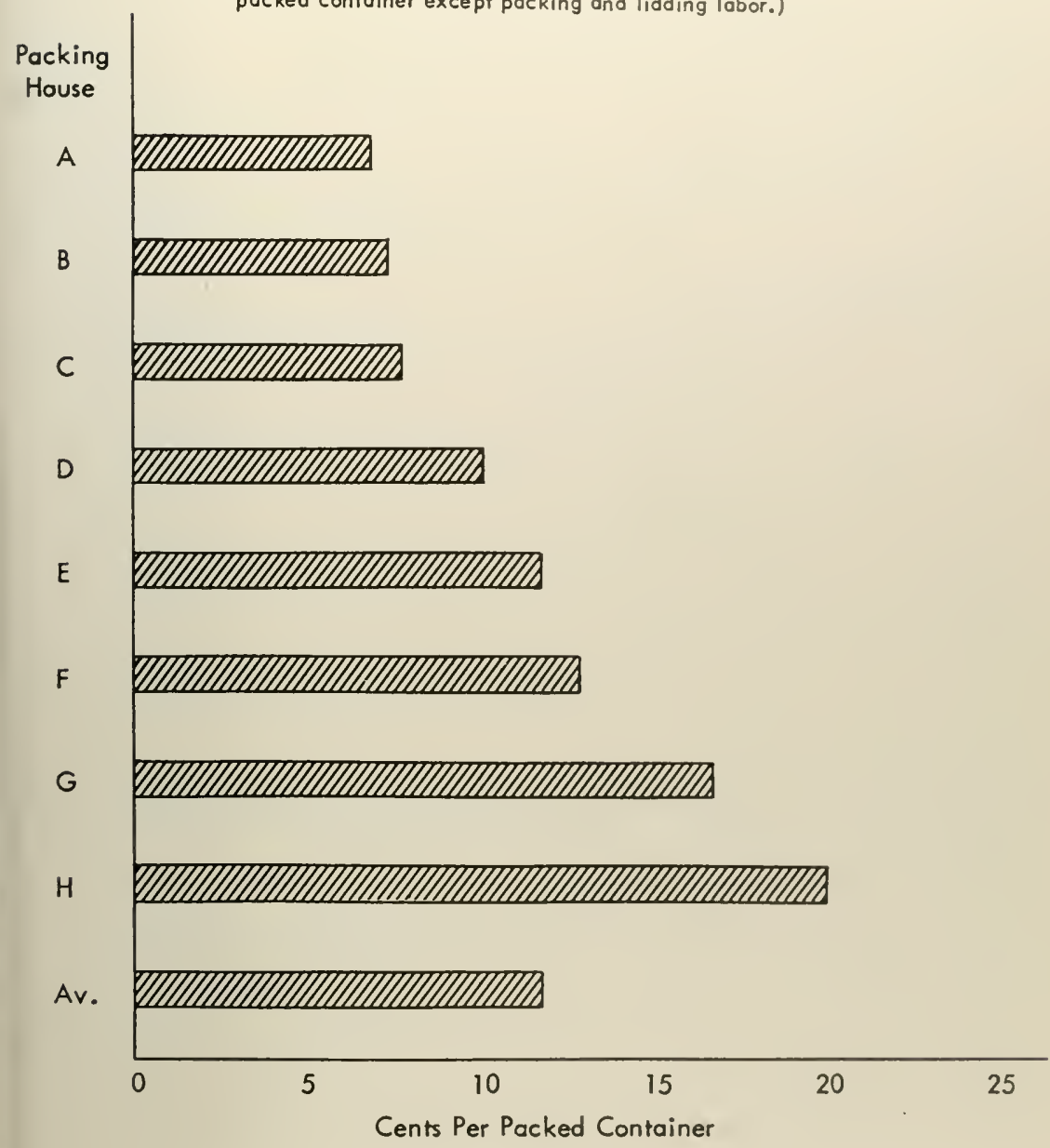

wats from a low of fi.9 cents per parked contaniner to a high of ? 2 (1) (1) (ents, with an average of 11.7 cents. Tible I shows a detaled breakdown, by jols, lor packing-house general labor.

By design, plants were selected which had to have the dilferent (ypes of machines and work methods used in 1956 by the larger Appalachian plants; consequently, there was a wide range in costs among plants. 


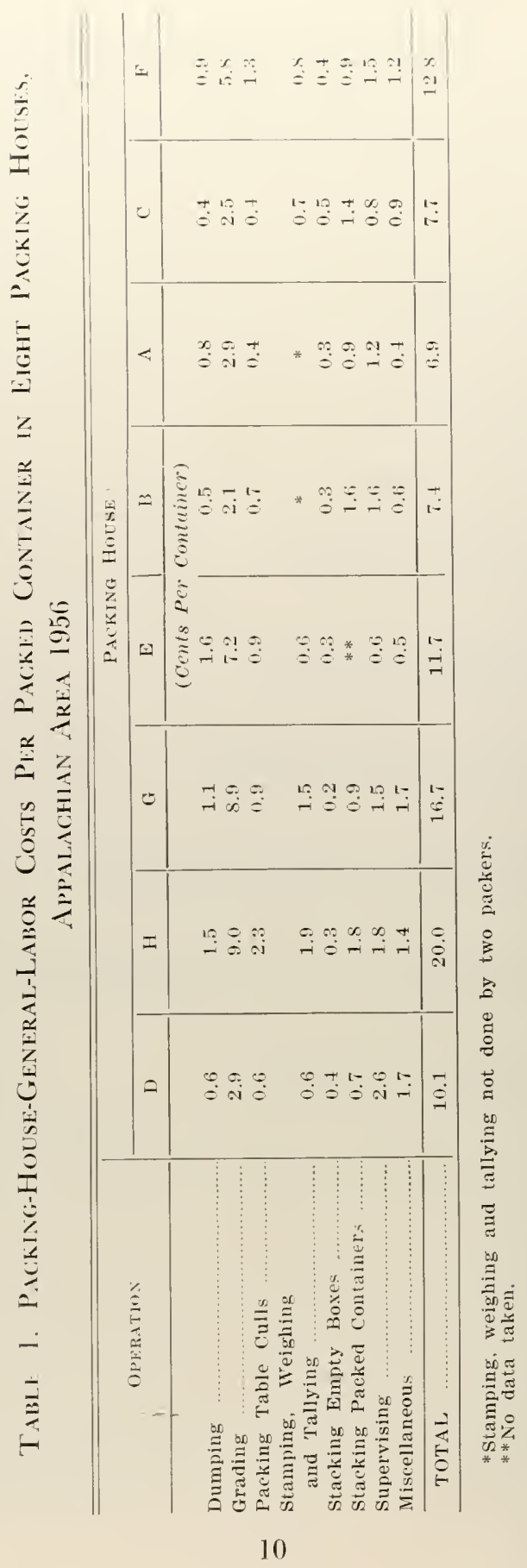


Figure 2 shows labor costs for packing and lidding, by plants, for the tray pack, Northwest box, and bushel basket. In cases where packes were paid on a piece-rate basis, that rate was used rather than labor requirements in man-minutes multiplied by wage rate. The tray pack was the most widely-used type of container. Packing-and-lidding costs for the tray pack ranged from a low of 3.2 cents per container (o a high of 13.5 cents, and areraged 8.9 cents. All eight packing houses surlied used the tray pack.

Four of the eight wsed the Northwest box, with a range in packingand-lidding labor costs from a low of 10.9 cents per container to a high of 18.1 cents, and with an average of 13.6 cents.

Three packing houses used the bushel basket. Packing-and-lidding labor costs ranged from a low of 7.6 cents to a high of 18.6 cents, with an average of 12.1 cents per packed basket.

\section{OVERHEAD COSTS}

Overhead costs were computed on a per-packed-containcr basis rather than on the number of bushels dmmped. This was based on the assumption that a packing house is not needed for selling apples to the processor; consequently, all packing-house costs should be charged to packed apples. Picture 3 shows typical packing-house equipment. Overhead costs ranged from a low of 5.7 to a high of 18.7 cents per packed container, with an average of $10 .()$ cents-Figure ?.

\section{CONTAINER COSTS}

Container costs accomnt for a major part of total packing-house costs. Table 2 shows the average, high, and low costs for the tray pack, the basket, and the Northwest box containers, complete at the packing line. Among plants, there was little variation in costs for the same type and quality of container. However, there was considerable variation in the cost of a particular type of container, depending upon its materials, construction, and finish. This was particularly true for the tray pack. depending on whether or not it was suitable for storage. Therefore, the variation in cost for a particular type ol container, as shomm in Table 2, was duc to variation in the quality of the container and not (o) vaniat. ion among plants for the sime quality of a patricular (ontainer.

\section{IOTAL COSTS}

Average total costs for palcking apples in l!) 56 in the cight platm eudied were 86.2 cents for the bushel basket, 90.7 rents for the trat rack, and 10.3.7 cents for the Northwest box, Figure t. The contanines, onplete at the packing line, was the langest single cost item in packing pples for the fresh market. The container, on the arclage, represented pproximately two-thirds of total packing costs. 1,atore was the noxtirgest packing-cost item, and overhead cost wals least. 
Figure 2. Packing-and-Lidding Labor Costs, in Eight Packing Houses, Appalachian Area, 1956.

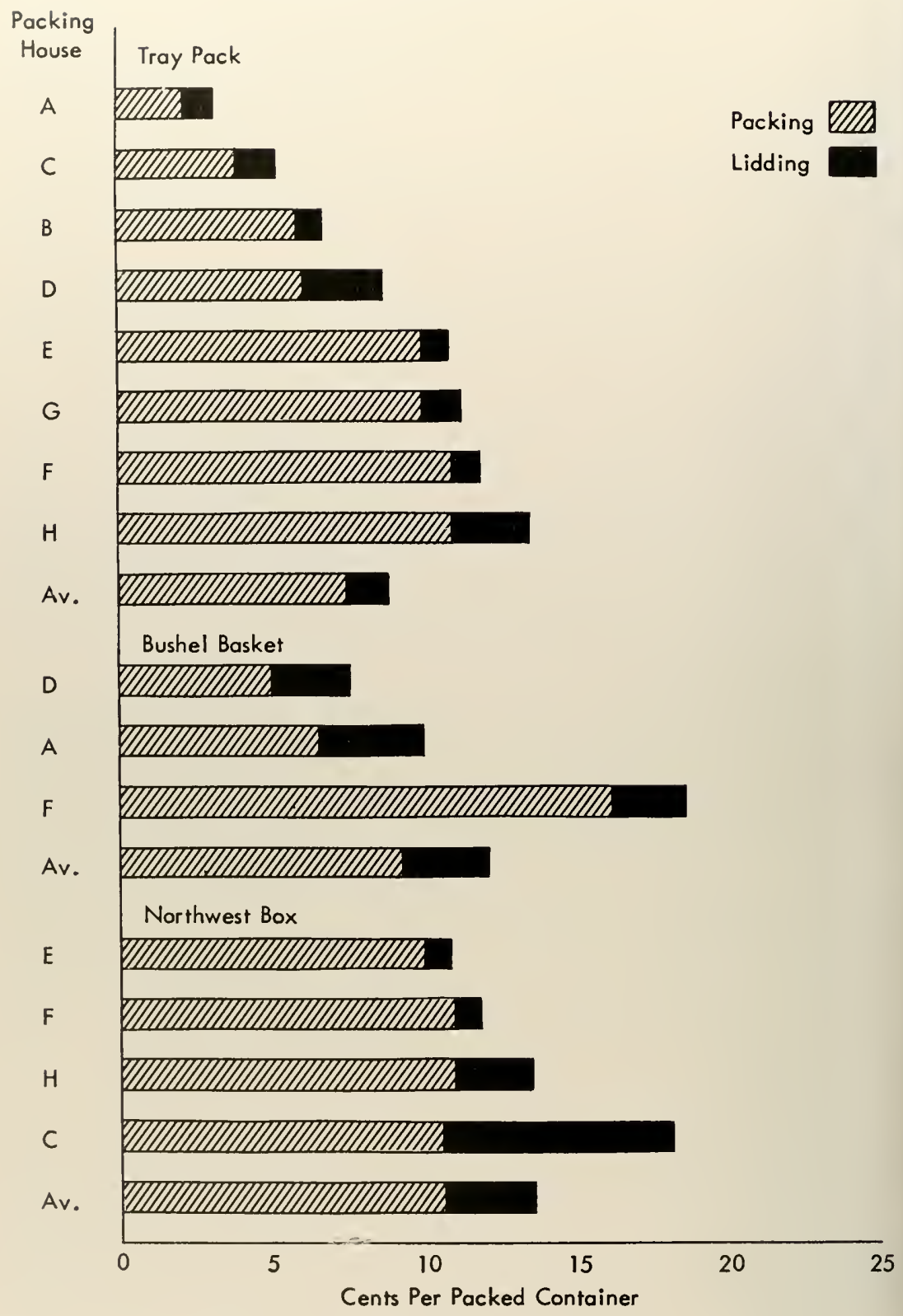




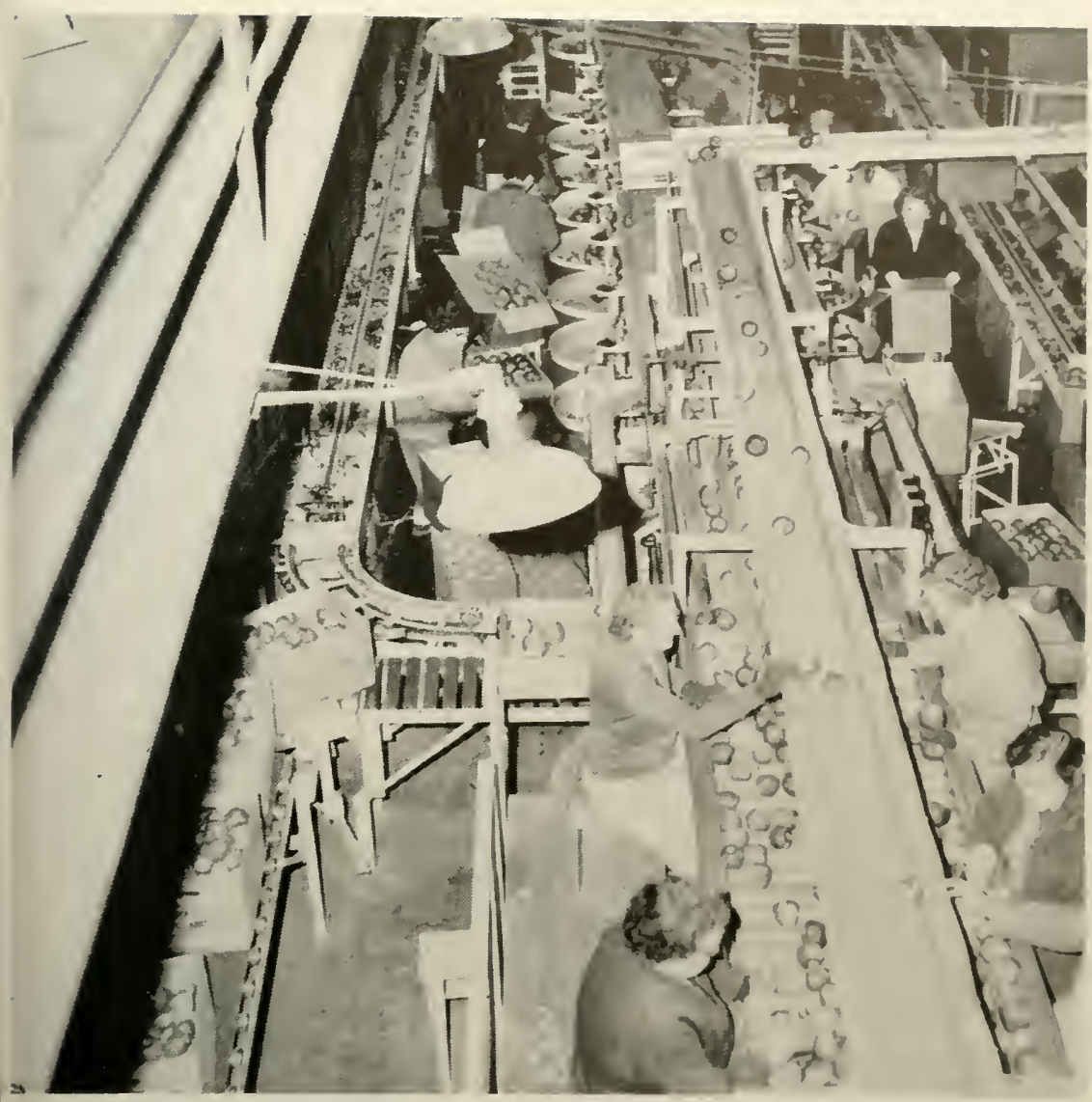

PICTURE 3-Typical packing-house equipment.

\section{Handling Costs}

With the adoption of the use of the inclustrial fork-lift truck. ome apple growers have changed considerably their methods of handing apples and possibly their costs of doing the job-Picture 4. In 1957. a study was made of the costs of handling apples, including both reeiving and loading-out operations.

\section{ECEIVING COSTS}

Figure 5 shows the handling costs of three growers for moving me-hundred crates of apples from under the tree to the packing house. These costs included only the costs involved in loading and unloading he apples and did not include the costs of the truck and driver from 
Figure 3. Overhead Costs Per Packed Container, in Eight Packing Houses, Appalachian Area, 1956.

(Other overhead includes repairs, light, heot, power, telephone, insurance and taxes.)

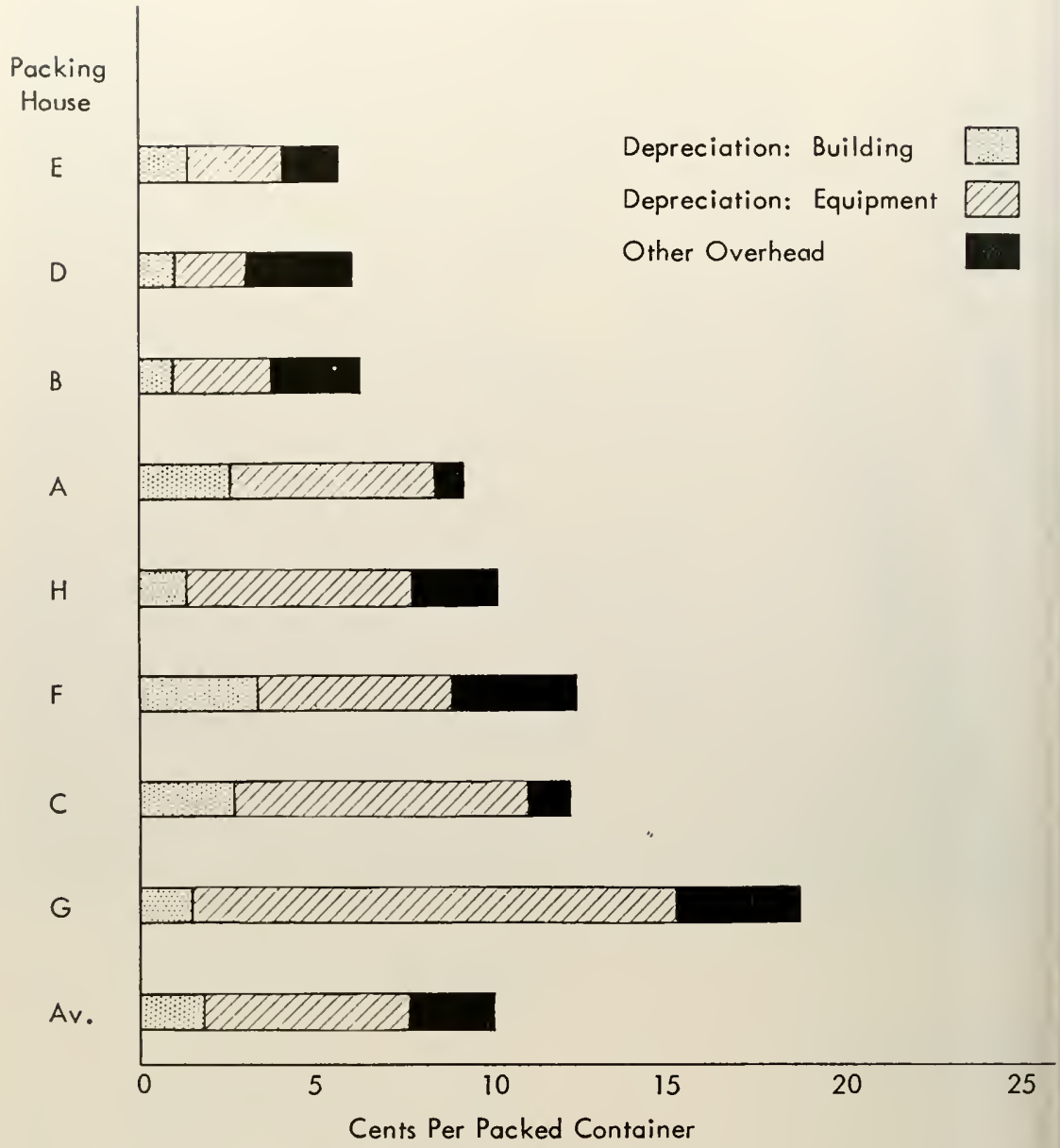

Table 2. Container Costs by Trpfo of Contaner (Complete and) al thl: Packing Station) In Eight Pagking; Holses, Appalachian Aria 1956

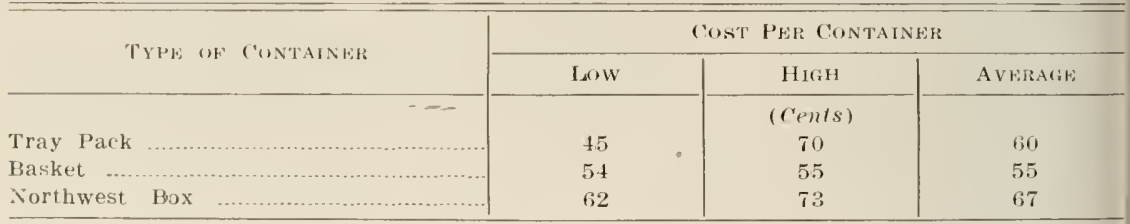




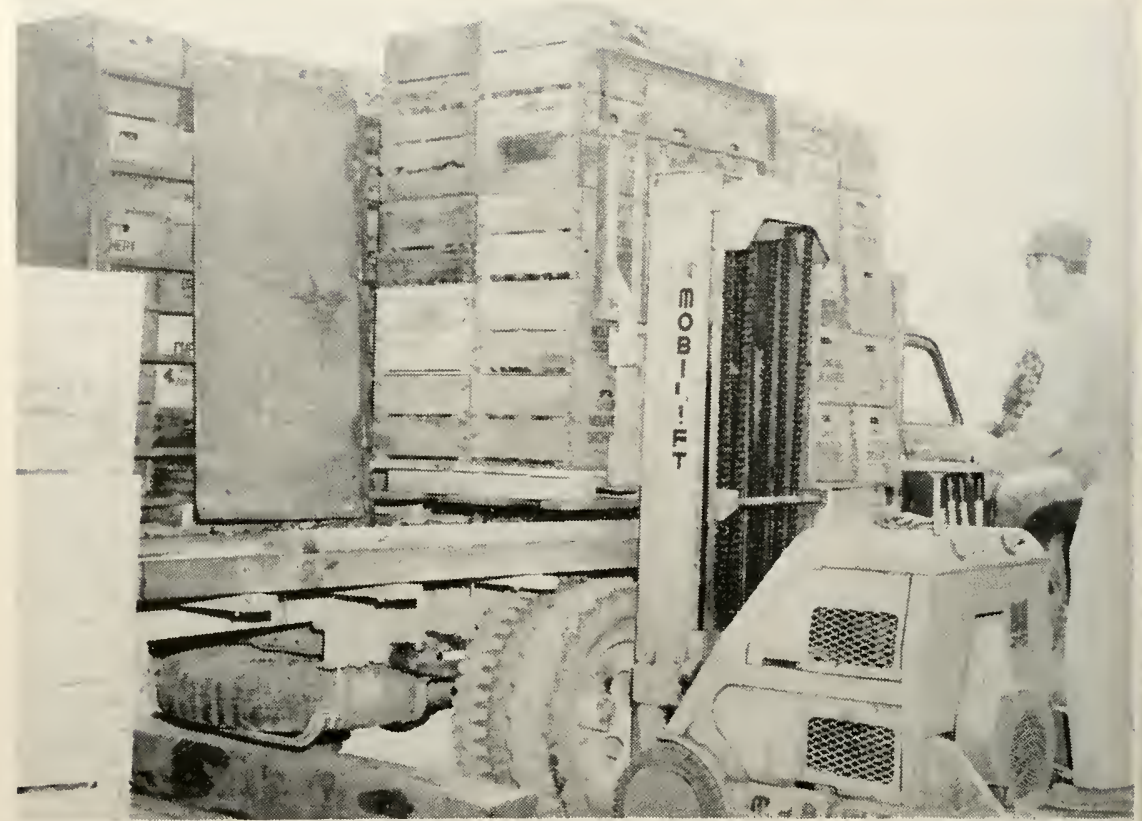

PICTURE 4-A fork-lift truck.

for C. A constant rate of $\$ 1.63$ per hour was charged to all growers for the use of a lork-lilt truck. ${ }^{1}$ Actual wage rates or piece rates paid by the growers studied, were used. In the case of grower $\mathrm{C}$, a piece rate of 2 cents per crate for loading in the orchard was paid. This made costs of that method relatively high.

\section{LOADING-OUT COSTS}

Figure 6 shows the handling costs for loading out one hundred packed containers at seven different packing houses. Actual wage rates paid by the different operators were applied, and $\$ 1.63$ per hour was charged for all fork-lift truck time. The range in costs was from a low of $\$ 0.47$ to a high of $\$(0.83$.

"This rate was taken from "Apple Handling Methuds and Equipment in Pacific Northwest Packing and Storage Houses." Niarket Research Report No, 49, PMA, USDA, 1953. This report also gives the method used in arriving at a rate of $\$ 1.63$ per hour. 
Figure 5. Selected Handling Costs from Tree to Packing House, Appalachian Area, 1957.

\section{GROWER and METHOD}

\section{Grower A}

Loading: One man on the ground moves field crates onto the truck; one man on truck places field crates on the pallets.

Unloading: One man with fork-lift truck sets pallets off the road truck onto a concrete platfarm and removes the pallets to temporary storage while the road truck returns to the orchard.

\section{Grower B}

Loading: Three men on ground load field crates directly to pallets on the orchard trailer.

Unloading: One man with fork lift unloads the trailer at paved central points in the orchard.

Loading: One man with fork lift loads the road truck at the central point.

Unloading: One man with fork lift unloads the pallets from the road truck to temporary storage.

\section{Grower C}

Loading: One man on the ground maves field crates onto the truck; one man on truck stacks field crates on the truck.

Unloading: Four men manually unload field crates from the road trucks, and place them on roller conveyors; remove them from conveyor and stack.

\section{Machine Costs \\ Labor Costs WZle}
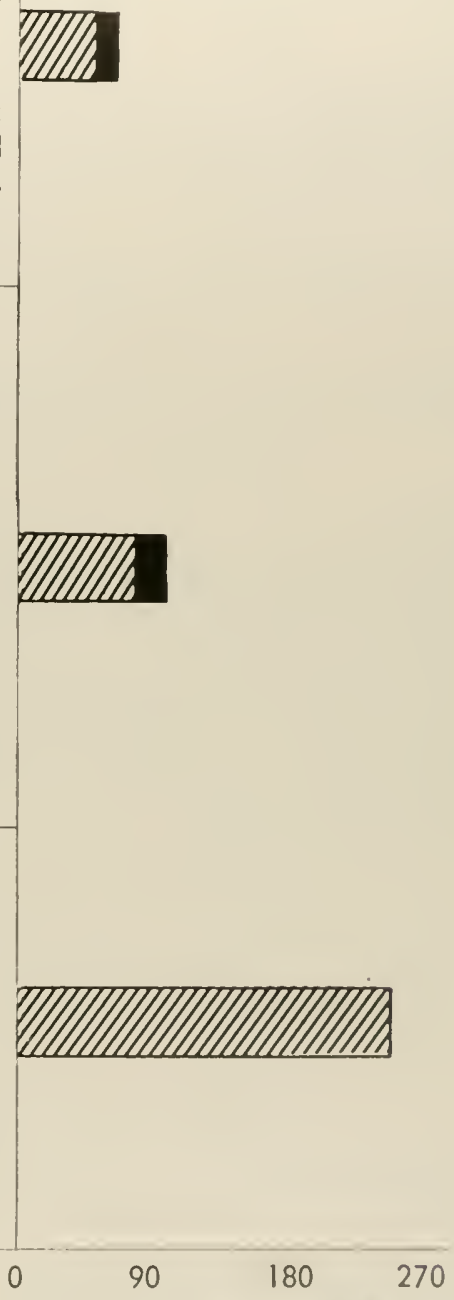

(Cents per 100 Contciners) 
Figure 6. Handling Costs for Looding-Out Pocked Apples, Appalochian Area, 1957.

PLANT and METHOD

\section{Plant A}

One fork-lift operator places pallets on the truck.

Five men remove boxes from pollets and stock in the truck.

\section{Plant B}

Four men monually move boxes from stack to conveyor.

Two men remove boxes from conveyor and stock them in the truck.

\section{Plant C}

Four men ploce boxes on the conveyor. One mon pushes boxes olong the conveyor.

Two men stock boxes in the truck.

\section{Plant D}

One mon with fork lift places pollets on the truck.

One man removes boxes from pollets and stocks them in the truck.

\section{Plant E}

One man with fork lift ploces pallets on the truck.

Two men remove boxes from pollet and stack them in the truck.

\section{Plant $F$}

One man with fork lift places pallets on the truck.

Two men remove boxes from pallets and stack them in the truck.

\section{Plant G}

Two men place boxes on conveyors in the cold storage room.

One man pushes boxes along the conveyor.

One man stocking boxes in the truck.
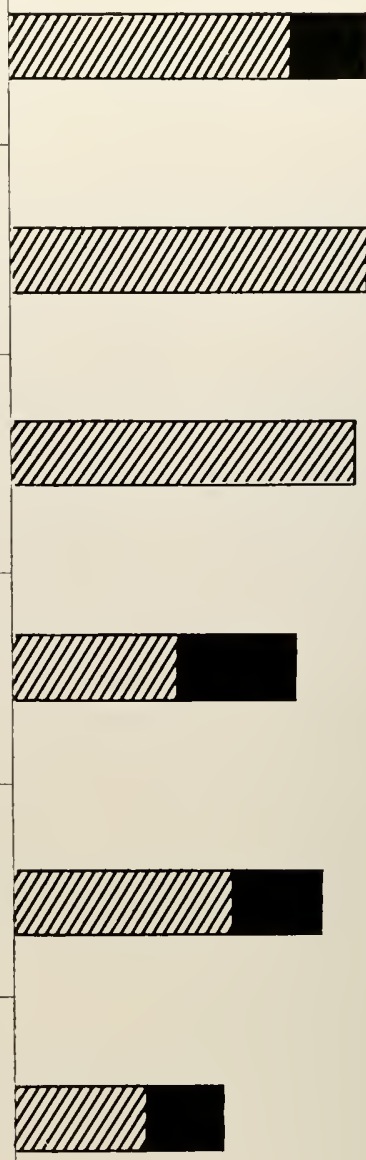

西

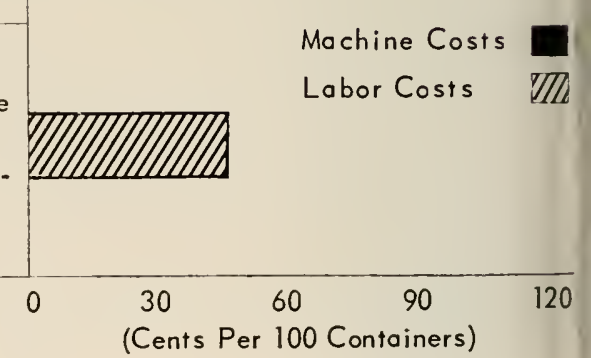


The field-crate de-stacker and attomatic-field-crate-filting device were not tested for their clamage to fruit. It is probable that the two machines produce less bruising to apples than the average manual operation for these two jobs. The two packing houses with the antomatic-crate fillers used then exclusively for handling culls and oft-grade lruit.

\section{Injury on Arrival at Packing House}

The first analysis of injury was made when the apples arrived in field crates at the packing-house floor for cleaning, sorting, sizing, anc packaging. As shown in Table 3 , the range of bruise-free fruit was fron 34 to 98 per cent. The two orchardists who had the least and the mos bruised fruit as it arrived at the packing house both used pallets. Every thing else being equal, the use of pallets should reduce mechanical in jury to the fruit. Two growers handling apples in individual-field crate without pallets had 60 and 80 per cent of bruise-free fruit. There is at indication that quality was maintined in transporting the palletizer fruit from the orchard to the packing house.

\section{Mechanical Dumping Versus Hand Dumping}

The greatest variation in the amount of bruising was found is apples dumped on the receiving bett by hand or mannal methods. On operator was able to place the fruit on the receiving belt without caus ing any additional bruising. Another operator added from 27 to 50 pe cent bruising by hand dumping. There was less variation in bruisin when dumping was done by mechanical means. In four packing house where a drum dumper was used, from 2 to 8 per cent of the fruit wa bruised. One straight-line dumper added 6 per cent bruising. Fror these results, it would seem that mechanical dumping could be used $i$ some operations to reduce the wide variation found in the hand 0 manual methods-Picture 1.

After the apples are clumped on the receiving belts they trave through a brushing or cleaning machine. These machines are very muc alike and added up to 10 per cent mechanical damage to the frutit. On packing-house operator removed the top unit of brushes or polishin cloths lrom the cleaner and replaced it with a medimm-weight floc rug which eliminated more than one-hall of the mechanical damag usually caused by brushing the fruit.

\section{Injury from Elevator Chains and Sorting Rolls}

Elevators and sorting rolls were very similar in all plants surveye except in two cases. In one packing house, the ordinary or usual woode 


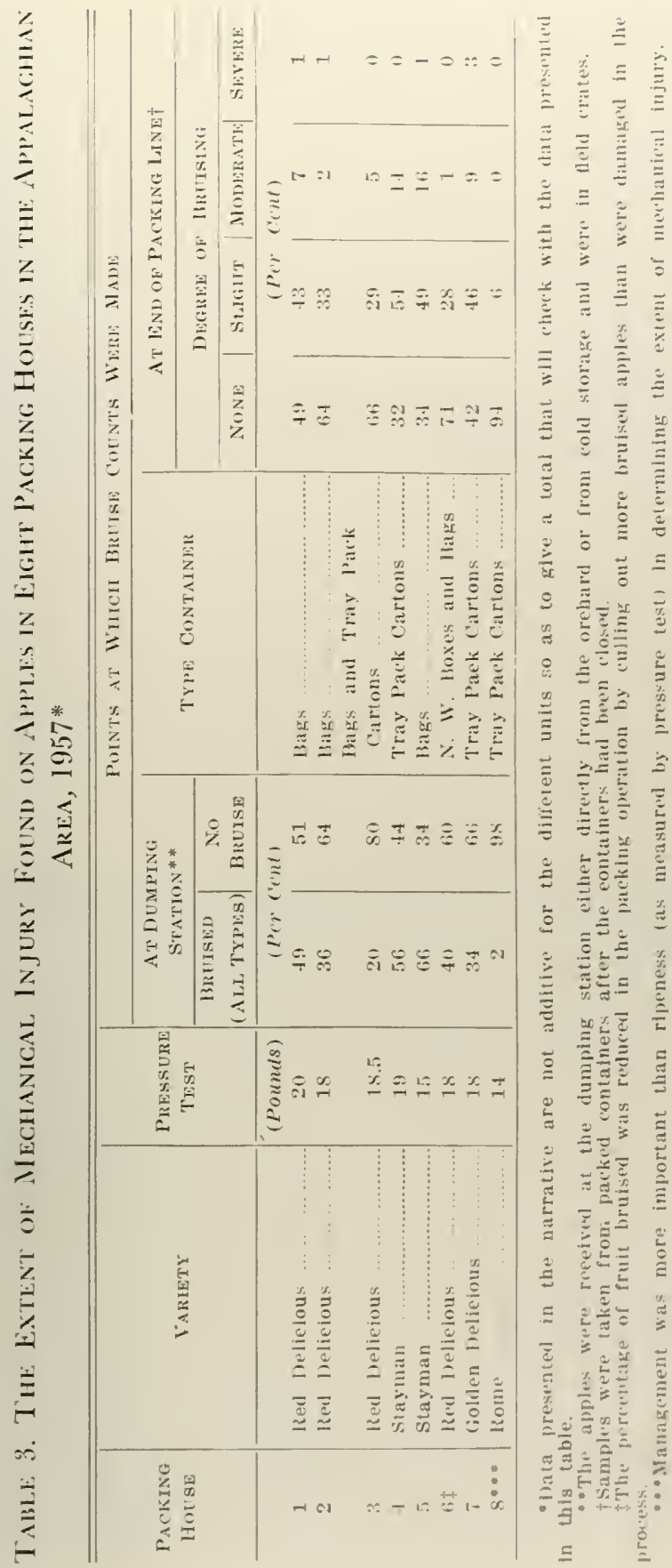


mols were coreded with felt to reduce butsing-Picture 5. 'T his was all improsement, and with the slow speed of mathinery in this patticula operation, there was no damage to the linit as it passed up the elevator and orer the sorting rolls. In another packing house where a lloat-roll sorting table was used, bruising was 2.6 per cent. The other six packing houses showed bruising from clevators and sorting rolls of from l to 10 per cent. Some of this variation can be accomtuted for by the speed of operation and height of the diop from elevators to sorting rolls. Also, sorting for color and blemishes, as separate operations, subjected the apples to additional lime and hazard on the machines. With slower speeds, with less drop hom elevator rolls or chains, with the use of cloth brakes over apples coming down inclines and with felt covering on the ordinary wooden rolls, it is possible to climinate bruising on this area of packing-house machinery.

\section{Sizing Machine Damage}

The Cutler or weight-type sizer was used in six of the cight parking houses surveyed. In one house, a rapid sizer was nsed-Picture 6. In two packing houses, the chain-si/ng method was used.

The Cutler on weight-type sizing machine was found to cause from 2 to 6 per cent bruise damage, with an average of 4 per cent. The source of injury in one case was due to the singulator wheel being out of ad-

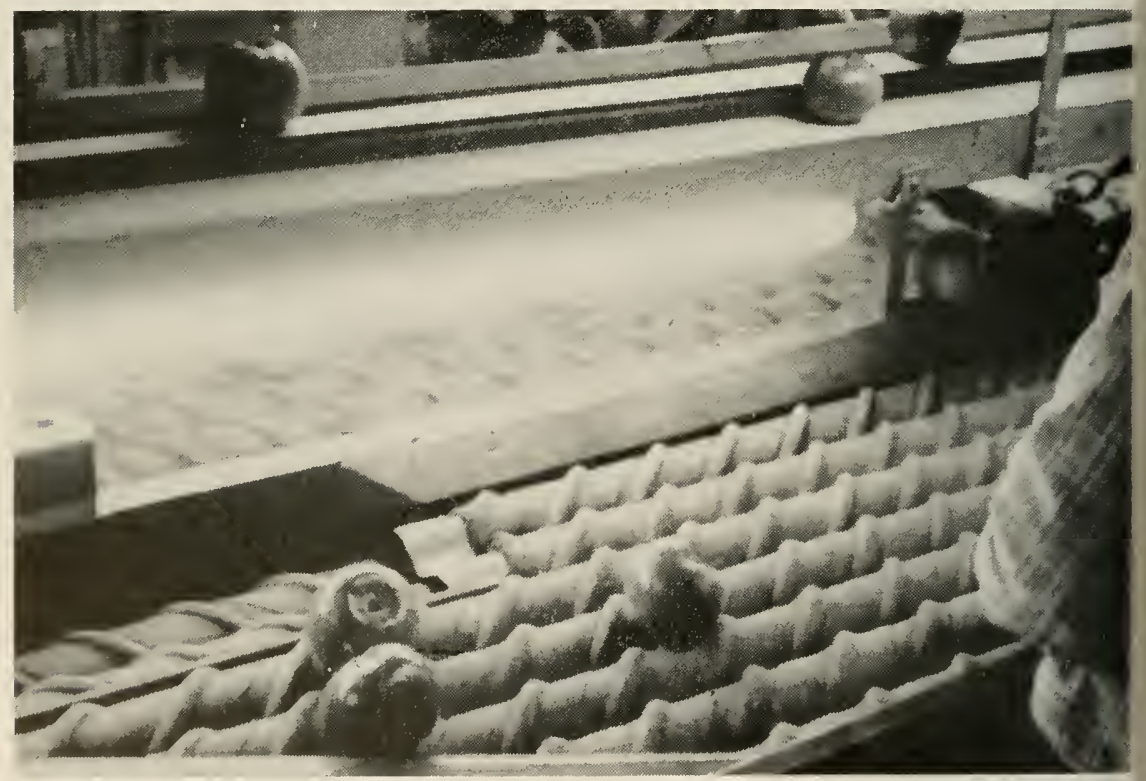

PICTURE 5-Felt-cover-sorting rolls. 


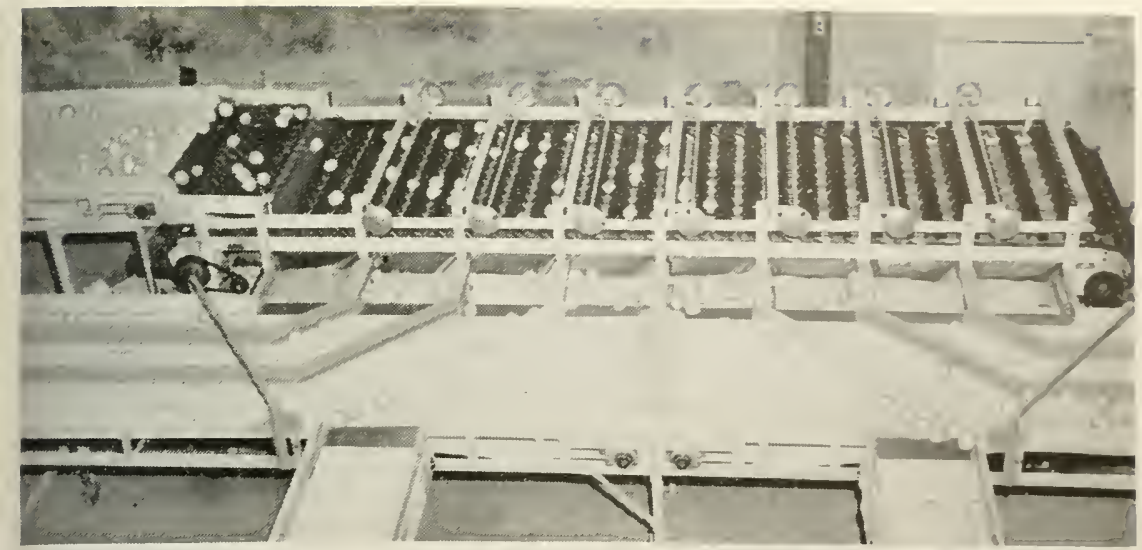

PICTURE 6-Sizer unit (dimensional-type sizer based on principle of gradually expanding plastic cups).

justment. With this type of machinc, most of the damage was done w apples clropping from the cup and hitting each other in the (ub). In) one house, a longer-than-standaud canvas apron was usect, with a pat of lelt on the underside to help brake the fall of the apples from (up to tub. This felt underpad seemed to add polish to the apples as (he tub revolved. Along with this improvement, a one-hall-inch-thick shcet of sponge rubber was used, measuring $8 \times 10$ inches, with 3 fingers rut into it. These fingers acted ats a brake on the top side of the apples when they dropped from the cups to the tubs-Picture 7 .

The chain sizers, when properly used, averaged o per cent mediunical damage. Here again, the drop through the chain to a moving belt below bruised the apples when they came in contact with each other. Frequently an apple was bruised and its skin broken when it becance wedged between the chain and a roller.

The rapid-sizer or plastic-oup dimension-type machine averaged 3.5 per cent bruising-most of which occured when the fruit dropped from the (ups to a moving belt for delivery to the take-off bins. This machine las a large capacity for the floor space it occupics.

\section{Jackaging Damage from the Take-Off Areas}

Tray-pack boxes, comsmmer-size bags, and the Nomthest box were le parkage types used. For filling laals and boxes, hand plaring and alcking was practiced in all parking houses. All housen used some Mpe

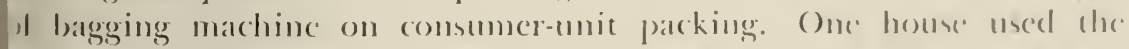

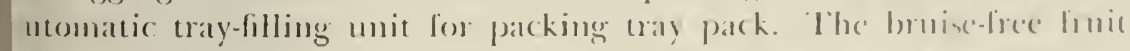
aried from 32 to 94 pere cent in the limal parkatge, as observed in the ight plants-Table 3. 


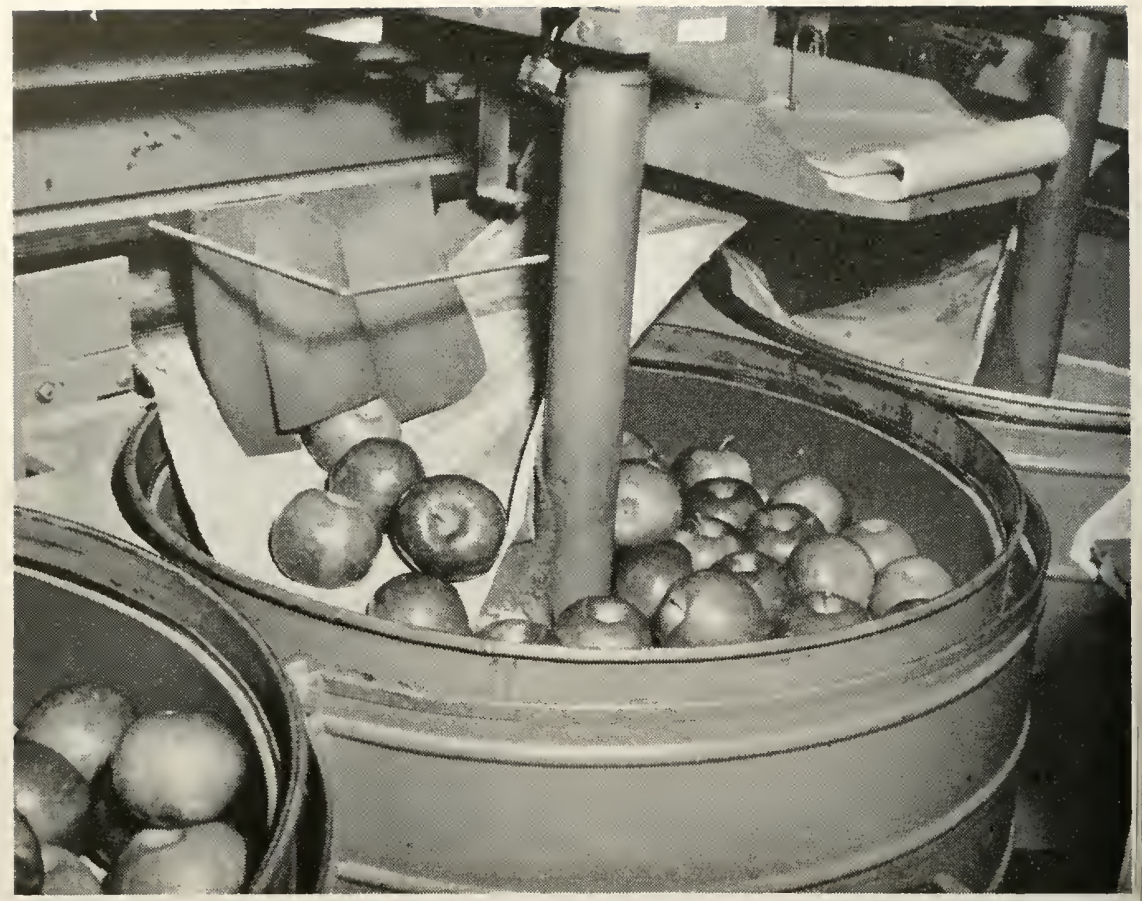

PICTURE 7-lllustration of how management improves standard equipment to prevent mechanical injury.

It was lound that where bagging machines were properly used, there was no bruising; however, when apples were run from the machine in a straight downward drop to the four-pound polyethylene bag, there was 9 per cent bruising-Picture 8 . When the fruit was allowed to run on a sloping drop into the bag, no bruise damage resulted.

It was found that the automatic tray-filler machine averaged 11 per cent bruising, but this may be due to manually forcing a filled tray to the botton of the tray box. Again, if this machine were properly operated and if the tray were allowed to settle by its own weight against a partial-air cushion, mechanical damage would be rechuced.

The hand placing of fruit into tray and box packs caused no dannage.

\section{Summary}

The most significant findings of this study are: the wide variation in packing and handling costs and mechanical injury to apples among operators; and the lack of any relationship between packing costs and mechanical injury. This suggests that there is an opportunity for most operators to reduce both costs and mechanical injury. If all operators 


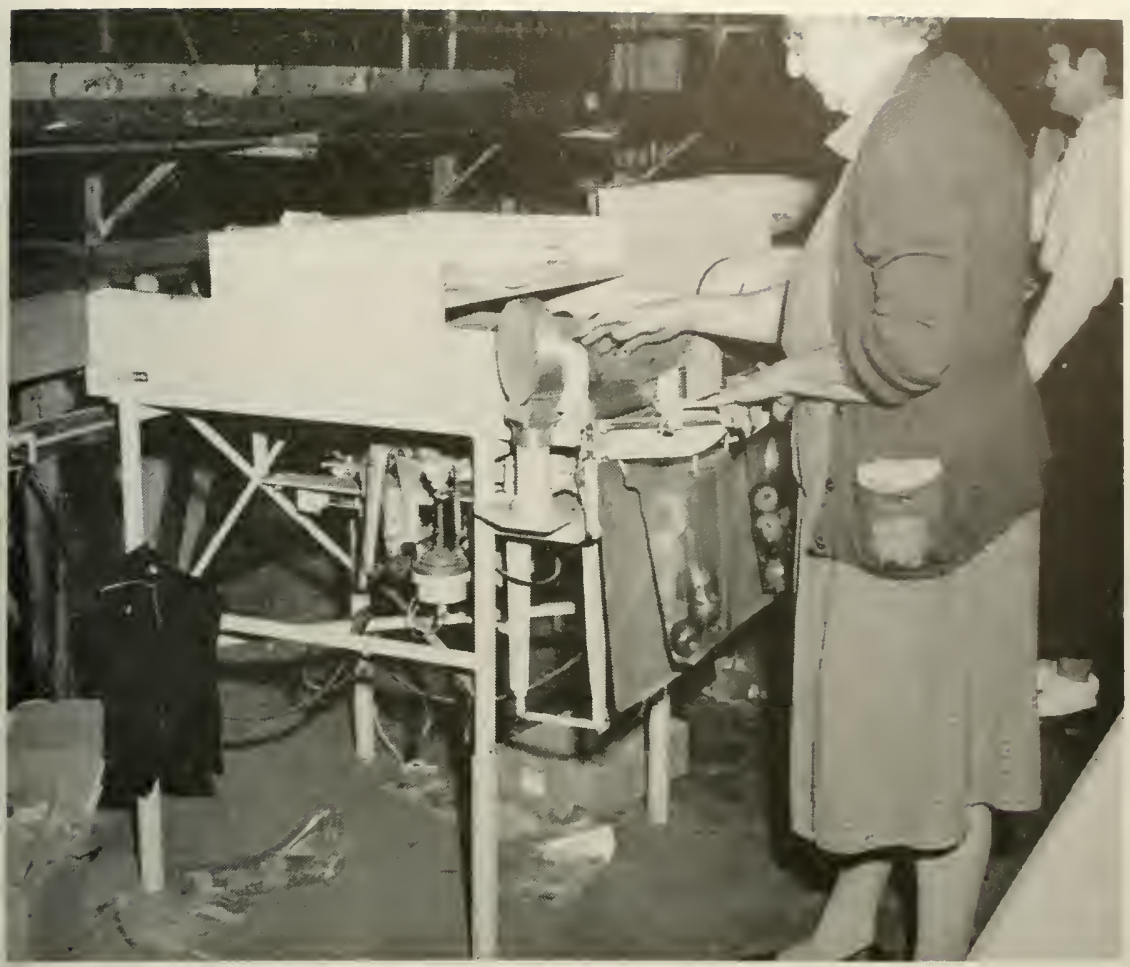

PICTURE 8-Bagging Machine.

could become ats cfficient as the lorrest-cost operators, the costs of parking and handling apples in the Appalachian Area rould be reduced considerably. No doubt, even the present low-cost operators could further improve their methods. This would mean even more silvings in packing and handling costs.

On the average, the total packing cost for the tray pack wats S(1.9)!, or the bushel basket, $\$() .86$, and $\$ 1.04$ for the Northwest box. Since sacking costs are not involved in sales to the processon, apple. grumers. m the average, would have to receive lrom $\$(1) .86$ to $\$ 1.01$ more per acked bushet sold to the fresh market than an moucked hushel wold a the processon market in order to receive the sance net from the ano utlets. The lowest-cost packer would have to receire ouly st).7!l per mshel more from the fresh than from the processor matke lo receive he same net; whereas the highest-cost parker would have to recrive' 1.II more from the fresh. This is on the assmmption that apple tualio,

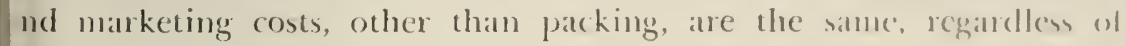
larket outlet used. To the extent that there alle differences, these dit rences would have to be taken into consideration. 
Except for costs of road truck and driver, handling costs for moving one hundred crates of apples from under the tree to the packing house ranged from a low of $\$(0.69$ to a high of \$2.53. Handling costs for loading out one hundred pack contaniners ranged, anong packers, from a low of $\$ 0.47$ to a high of $\$ 0.83$.

In general, no machine tested could be condemned because of excess truit bruising. However, most of them could be improved through better enginecring and designing. Ahhough consuners tolerate a reasonable amount of bruising on apples, it is probable that they will be less tolerant in the luture. Continued engineering research to improve present machines is essential, and crentually new principles for sizing, sorting, and packaging will be needed. The fresh-fruit packaging plants operating with larger volumes, as indicated by present trends, will be employing new machines in the future, using electronic, pnemuatic and hydraulic devices which are not even on the designing boards at present.

The amomnt of mechanical damage which occurs in today's packing houses varies more with managenent and supervision than it does with the particular type of machinery. These lactors of management deal with machinery adjustments, persomnel training, and a smooth but flexible design and layout.

The findings of this report offer encouragement for reducing packing and handling costs and mechanical injury in the Appalachian apple industry. From the time and motion and work sampling data to be presented in another report, an attempt will be made to synthesize a low-cost packing and handling method. If possible, the synthesized method will be field tested for operating costs and mechanical injury to apples. 